\title{
ECONOMIC ASSESSMENT OF RECONSTRUCTION NEEDS
}

\author{
Romualdas Tamošaitis \\ Vilnius Gediminas Technical University, Department of Construction Technology and Management, \\ Saulètekioal.11,LT-10223Vilnius, e-mail:roma@adm.vgtu.lt
}

Received 1009 2009; accepted 05102009

\begin{abstract}
Durability and aesthetic appearance are important elements of all buildings, but the need for reconstruction is often influenced by the economic considerations. We often decide to reconstruct industrial buildings in order to increase profits and we choose to reconstruct residential houses to save money on heating or maintenance expenses. This article deals with a mathematical method for economic assessment of reconstruction needs. The mathematical method used in this article is based on evaluating the break-even point between the reconstruction expenditures and the economic profit. The relationship between the economic profit and the reconstruction expenditures is usually quite complicated as it may take a non-linear form and result in several break-even points. The main goal of an economic assessment in reconstruction usually concerns finding the rational solutions between several break-even points.
\end{abstract}

Keywords: construction, reconstruction needs, critical point method, break-even point method.

\section{Introduction}

Laws in many countries make a clear distinction between reconstruction and repair works.

Repair of construction works means a type of construction aimed at partly or totally restoring the properties of construction works or a part thereof set by normative technical construction documents, which have gotten worse because of the exploitation of a construction works, or at improving the said properties.

Reconstruction of construction works means a type of construction with the aim to change essentially the existing construction works, thereby creating entirely new quality.

Many sources make a link between the economic evaluation of a building's reconstruction needs and the longer building life time and additional value creation (Venckevičius 2004). Yet it is often forgotten that the cost of a building itself constitutes a relatively small portion of the total real estate value. A very frequent situation, particularly in the residential home market, is that a buyer of a relatively new residential building will choose to demolish it completely in order to build a new home that more closely reflects his/her personal needs and aesthetical preferences. Life time, durability and aesthetic appearance of buildings are important indicators of buildings, but the need for reconstruction is often influenced by economic interests. Industrial buildings are often reconstructed in order to increase profits and residential houses are reconstructed to save money on heating or maintenance expenses.

In the light of rising energy costs, the issue of heating is becoming particularly relevant (Blanco et al. 2009; Artmann et al. 2008). In an effort to respond to the high heating costs, a concept of a passive house has been created (Mingozzi et al. 2009) and first examples of such homes have already been built. The question remains, however, if such concept makes economic sense. After all, thermo isolating materials also require a lot of energy and it may be cheaper to invest in the alternative energy sources instead. Answering the question of what the optimal reconstruction cost should be is the central goal of this article.

Depending on the reconstruction needs, it is also possible to apply the assessment methods that take into account multiple goals, like the multi-objective MOORA optimization method (Brauers, Zavadskas 2009). However, the main issue in this situation is that the methods which evaluate multiple goals can be only ap- 
plied when all of the potential reconstruction alternatives are known. Needless to say, it is very difficult to satisfy this assumption and thus to apply these methods.

As one can see from the examples provided below, it is sometimes possible to have two reconstruction alternatives that rely on the same type of construction structure and employ the same kind of materials yet, under certain conditions of use, one of them will be economical and the other will not. For these reasons, the article provides a new methodology that employs the break-even point analysis to select the economically optimal reconstruction alternative.

\section{Traditional evaluation of reconstruction needs}

Traditional evaluation of reconstruction needs is usually linked to the extended lifetime of a building (Venckevičius 2004). It is often assumed that money invested in building's reconstruction will proportionally increase its life time. In reality, this does not always happen. The effectiveness of a reconstruction with regard to the lifetime of a building can be evaluated by the following formula:

$\frac{K_{1}}{T_{1}} \leq \frac{K_{2}}{T_{2}}$,

where: $K_{1}$ - cost of reconstruction taking into account changes in the residential area and other factors, $T_{1}-$ lifetime of a building after the reconstruction; $K_{2}$ - cost of building a new identical building of the same size, $T_{2}$ - lifetime of a new building.

It is apparent from the formula (1) that the lower is the reconstruction cost and the higher is the building's lifetime, the higher is the probability of full reconstruction cost recovery. Such traditional philosophy of building's reconstruction effectiveness is based on the impact of building's renewal on its useful lifetime (Fig. 1).

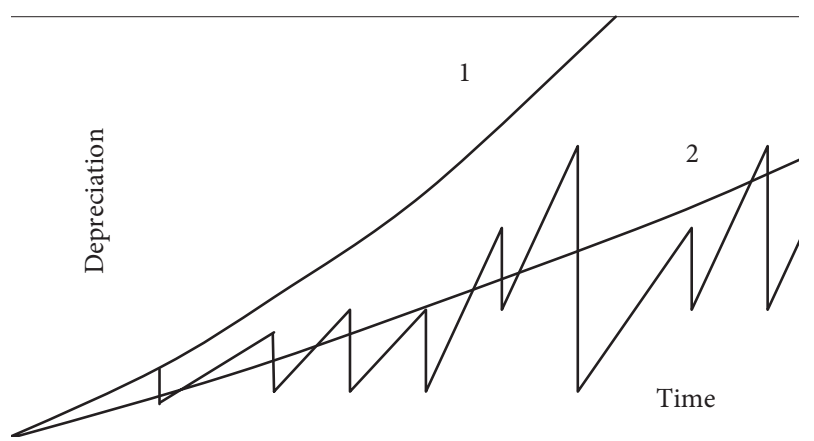

Fig. 1. Building depreciation process: 1 -natural building's depreciation process, 2 - building's depreciation process when the building is well maintained

\section{Break-even analysis method}

In economics, break-even point is the point at which project revenues equal project costs (Blaug 2007). Revenues are usually directly dependent on the developed and sold product quantities. Costs, on the other hand, may be fixed and variable with regard to production and sales. Fixed costs are costs that do not depend on the sold product quantity. These costs may entail administrative expenses, loan repayments, etc. Variable costs are costs that are dependent on quantities produced. These costs entail labor costs, material costs, machine rents, etc. As production and sales increase, so do the variable costs.

When production is low, revenues may be lower than costs and the activity will generate an economic loss. At a point where revenues are equal to the costs (break-even point), no profits are made yet but the activity is no longer resulting in a loss. Once the production and sales increase beyond the break-even point, economic profits are generated (Fig. 2).

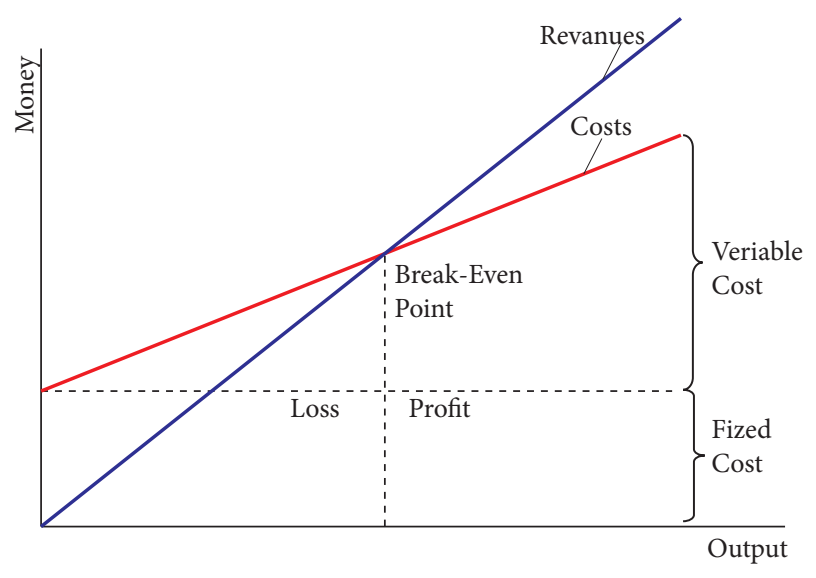

Fig. 2. Break-even point analysis method

Practice shows that variable costs are usually not linearly related to the size of production. When the non-linear relationship between the size of production and the costs exists, two break-even points can be found. The first break-even point indicates the starting point of a profitable production zone and the second break-even point marks the end of a profitable production zone (Fig. 3).

In the general case it is possible to determine the exact location of a profit zone by solving the following set of simultaneous equations:

$\left\{\begin{array}{c}C=P+V(g) \\ I=K \cdot g\end{array}\right.$, 
where: $g$ - size of production $C$ - production costs, $P$ fixed expenses; $V(g)$ - variable production costs, $I$ - revenues from product sales, $K$ - price charged per unit of a product.

In order to determine the production quantity that ensures the maximum profit, one must solve the following set of simultaneous differential equations:

$\left\{\begin{array}{c}C^{\prime}=V^{\prime}(g) \\ I^{\prime}=K\end{array}\right.$

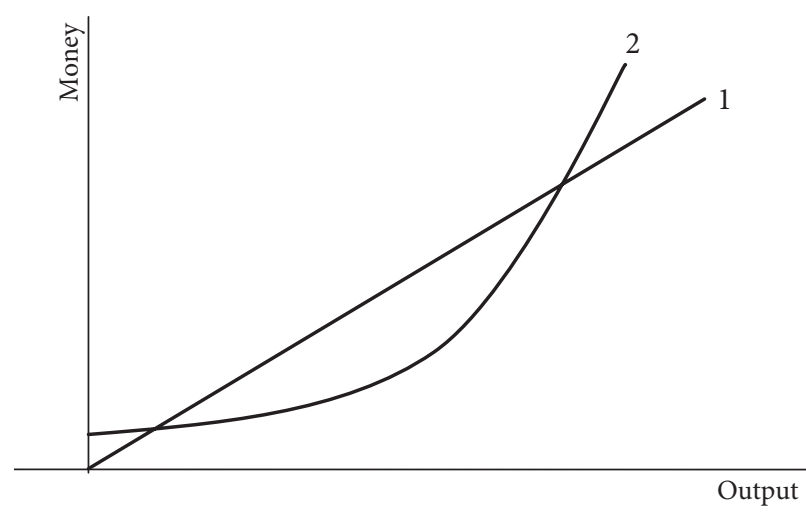

Fig. 3. Break-even point analysis method when non-linear relationship exists between costs and production size: 1 - revenues, 2 - costs

\section{Industrial buildings and break-even point analysis method}

Reconstruction of industrial buildings is often linked to the technological progress. Upon the arrival of new production technologies, an opportunity opens up to either produce more, higher quality products or to reduce the production costs. To exploit these new opportunities, companies must change their technological production lines which in turn requires changes in the building layout and introduces other building reconstruction needs. For this reason, reconstruction of industrial buildings should not be separated from the reorganization of the production process

The effectiveness of a reconstruction can be evaluated using the break-even point analysis method once reconstruction and production costs are added together. To evaluate reconstruction effectiveness, one needs, at minimum, consider changes in key production indicators, product quality and price as well as production size and production costs. Most often, product quality improves, production rises and variable costs diminish when reconstruction is implemented. Fixed costs (usually related to firm's debt related obligations), on the other hand, usually increase, at least temporarily. Fixed cost increase is closely related to the additional debt that a firm must take out in order to execute the reconstruction.

Few companies are in a position to self-finance the entire reconstruction process. Product quality is usually reflected in the product price. Therefore, as product quality rises, so does the product price.

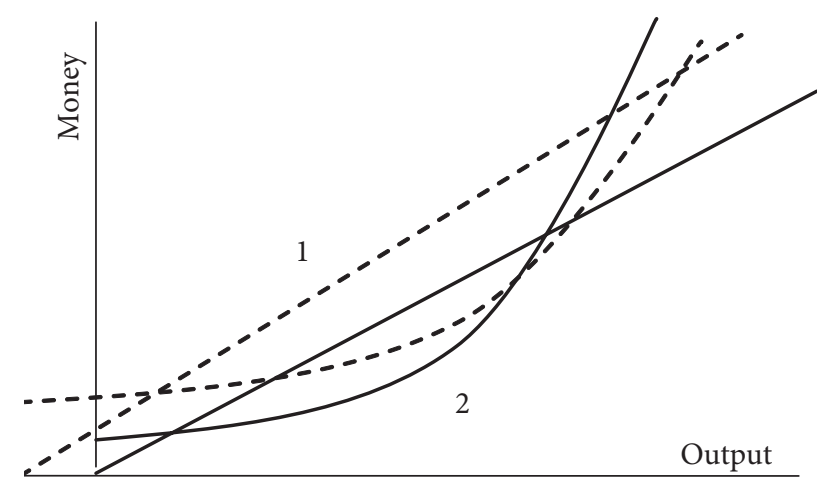

Fig. 4. Revenues and costs associated with an industrial building before and after the reconstruction: 1 - revenues, 2 - costs, - revenues and costs before the reconstruction, ----- revenues and costs after the reconstruction

Example. A company produces screws. Screw price is $10 \mathrm{Lt} / \mathrm{kg}$. Before the reconstruction, company's fixed costs are equal to $20000 \mathrm{Lt}$ per month, variable costs are related to the size of production $g$ by the equation $V=0.01 g+0.001 \mathrm{~g}^{2}$.

Company's profit range can be determined by solving the following set of simultaneous equations:

$\left\{\begin{array}{c}C=20000+0.01 g+0.001 g^{2} \\ I=10 \cdot g .\end{array}\right.$

Solution of the above equations indicates that in order to break even and avoid a loss, the company must produce a minimum monthly quantity of screws equal to $g_{1}=2770 \mathrm{~kg}$. The maximum monthly quantity of screws that a company can produce without incurring a loss is equal to $g_{2}=7220 \mathrm{~kg}$.

The maximum profit that can be obtained given the size of production can be determined by the following set of simultaneous equations:

$\left\{\begin{array}{c}C^{\prime}=0.01+2 \cdot 0.001 \cdot g \\ I^{\prime}=10\end{array}\right.$

In this case, maximum profit will be obtained when the monthly production of screws is equal to $4995 \mathrm{~kg}$. Maximum monthly profit is equal to $4950 \mathrm{Lt}$. 
After the reconstruction, the company must increase its fixed costs to $23333 \mathrm{Lt}$ per month due to an additional debt that it took out to finance the reconstruction process. The price that the firm charges for its product remains the same at $10 \mathrm{Lt} / \mathrm{kg}$. Variable costs would diminish to $V=0.005 x+0.0005 g^{2}$.

$\left\{\begin{array}{c}C=23333+0.005 \cdot g+0.0005 \cdot g^{2} \\ I=10 \cdot g .\end{array}\right.$

In this case, a reconstruction would expand the profit zone from $g_{1}=3842$ to $g_{2}=8627$. Solving the simultaneous equations

$\left\{\begin{array}{c}C^{\prime}=0.005+2 \cdot 0.0005 \cdot g \\ I^{\prime}=10 .\end{array}\right.$

we determine that the maximum profit would be obtained when $7995 \mathrm{~kg}$ of screws is produced on a monthly basis. Under this production size, maximum monthly profit would reach $8627 \mathrm{Lt}$. We can conclude that the reconstruction is profitable.

\section{Break-even point analysis method in building thermo-isolation decisions}

Break-even point analysis method can be also successfully applied in building thermo-isolation decisions. In this case, knowing changes in heating costs and the costs associated with thermo-isolation of walls allows the user to apply the break-even point analysis in order to determine the optimal amount of thermo-isolation materials.

Heat loss associated with external walls can be determined using the following formula (STR 2.05.01, 2005):

$\varphi_{e l}=A \cdot U \cdot\left(\theta_{i}-\theta_{e}\right) \cdot k \cdot T$,

where $A$ - external wall area, $U$ - heat transfer coefficient, $\left(\theta_{i}-\theta_{e}\right)$ - difference between the projected inside and outside temperatures during the heating season, $k$ - coefficient used to assess the orientation of a building, wind direction and other factors that influence the calculations, $T$ - exploitation hours, $h$.

Heat transfer coefficient $U$ is determined using the following formula (STR 2.05.01 2005):

$U=\frac{1}{R}$

If thermal resistance $R$ of a wall before the reconstruction is $R_{1}$, and the additional thermal resistance added during the reconstruction is $R_{2}$, then heat losses through an external wall before and after the reconstruction can be given by the following formulas:

$\varphi_{e}=A \cdot \frac{1}{R_{1}} \cdot\left(\theta_{i}-\theta_{e}\right) \cdot k \cdot T$,
$\varphi_{r}=A \cdot \frac{1}{R_{1}+R_{2}} \cdot\left(\theta_{i}-\theta_{e}\right) \cdot k \cdot T$.

Using these formulas, we can determine the postreconstruction heat savings as follows:

$\Delta \varphi=\varphi_{e}-\varphi_{r}$

In case the old thermo-isolation product is being replaced with a new one that meets a higher efficiency standard (as in when the windows get replaced), the total heat savings after the reconstruction are calculated by the following formula:

$\Delta \varphi=A \cdot\left(\frac{1}{R_{1}}-\frac{1}{R_{2}}\right) \cdot\left(\theta_{i}-\theta_{e}\right) \cdot k \cdot T$.

The annual savings when the building is heated with gas is equal to:

$S_{t}=\Delta \varphi \cdot \frac{g \cdot c}{1000}$

$S_{t}=\left(\frac{1}{R_{1}}-\frac{1}{R_{2}}\right) \cdot\left(\theta_{i}-\theta_{e}\right) \cdot k \cdot T \cdot \frac{g \cdot c}{1000}$

$S_{t}=A \cdot\left(\frac{1}{R_{1}}-\frac{1}{R_{2}}\right) \cdot\left(\theta_{i}-\theta_{e}\right) \cdot k \cdot T \cdot \frac{0.1073 \cdot 1.6}{1000}$

where $c=1,6$ - a Lithuanian gas cost, $\mathrm{Lt} / \mathrm{m}^{3}$ (in 2009 prices), $g=0,1073$ - gas quantity per $\mathrm{m}^{3}$ to produce 1 kWh of energy.

In case when an additional thermo-isolation layer is added to the existing one, the total heat savings are calculated as follows:

$\Delta \varphi=A \cdot\left(\frac{1}{R_{1}}-\frac{1}{R_{1}+R_{2}}\right) \cdot\left(\theta_{i}-\theta_{e}\right) \cdot k \cdot T$.

The total annual monetary savings (post-reconstruction heating costs as compared to the pre-reconstruction heating costs) when an additional layer of thermo-isolation material is applied can be calculated as follows:

$S_{t}=A \cdot\left(\frac{1}{R_{1}}-\frac{1}{R_{1}+R_{2}}\right) \cdot\left(\theta_{i}-\theta_{e}\right) \cdot k \cdot T \cdot \frac{g \cdot c}{1000}$. 
Thermal resistance $R_{2}$ can be linked to the thermo-isolation material thickness $x$. Accordingly, postreconstruction heat savings can be determined using the formula:

$\Delta \varphi=A \cdot\left(\frac{1}{R_{1}}-\frac{1}{R_{1}+f(x)}\right) \cdot\left(\theta_{i}-\theta_{e}\right) \cdot k \cdot T$.

The cost of reconstruction works can be evaluated using the cost of materials (which usually amounts to about $30 \%$ of total value of reconstruction works). In this way, the cost of thermo-isolation works $S_{r}$ can be roughly estimated using the following formula:

$S_{r}=k_{1}\left(S_{1} \cdot x+S_{2}\right)$,

where $k_{1}$ - coefficient measuring the impact of material cost to the overall value of reconstruction works, $x-$ thermo-isolation material thickness, $S_{1}$ - thermo-isolation material cost, $S_{2}$ - other materials cost needed for the reconstruction.

Example. A building is located in Kaunas, Lithuania, where the average outside temperature during the heating season is $-0,5^{\circ} \mathrm{C}$. Inside temperature is $+20^{\circ} \mathrm{C}$. The length of a heating season is 192 days. Current thermal resistance is equal to $R_{1}=2$. The characteristics of the materials used for the thermo-isolation purposes are given in Table 1 . The cost of materials makes up about 30 percent of total reconstruction process value. The cost of thermo-isolation material is $420 \mathrm{Lt} / \mathrm{m}^{3}$, other materials needed cost $15 \mathrm{Lt} / \mathrm{m}^{2}$.

Table 1. Thermo-isolation layer's resistance, when materials used for the thermo-isolation are $\lambda_{d s}=0.034 \mathrm{~W} /(\mathrm{mK})$

\begin{tabular}{|c|c|c|c|c|c|c|}
\hline Layer thickness, $\mathrm{mm}$ & 30 & 50 & 75 & 100 & 125 & 150 \\
\hline$R_{2}$ & 0.73 & 1.18 & 1.73 & 2.28 & 2.83 & 3.37 \\
\hline
\end{tabular}

From table 1 the user can see that in this case the resistance of the thermo-isolation layer is approximately equal to the thermo-isolation layer thickness $x$ in meters multiplied by 22.2 .

$R=22.2 \cdot x$.

The cost of materials makes up about 30 percent of total reconstruction process value. The cost of thermoisolation material is $420 \mathrm{Lt} / \mathrm{m}^{3}$, other materials needed cost $15 \mathrm{Lt} / \mathrm{m}^{2}$. Based on this, the correlation of the reconstruction costs to the thickness of the thermo-isolation material according to the formula (15) can be expressed as:

$S_{r}=3.33(420 \cdot x+15)$.

Consequentially, the amount of heat that could be saved during the heating season per one square me- ter of a wall according to the formula (14) is equal (in watts) to:

$\Delta \varphi=1 \cdot\left(\frac{1}{2}-\frac{1}{2+22.2 x}\right) \cdot(20-(-0.5)) \cdot 1.02 \cdot 192 \cdot 24$.

The amount of heat that could be saved over a certain number of years of building exploitation $(\mathrm{m})$ per one square meter of a wall is equal (in watts) to:

$\Delta \varphi=\left(\frac{1}{2}-\frac{1}{2+22.2 x}\right) \cdot 96353.28 \cdot m$

The savings when the building is heated with gas is equal to:

$S_{t}=\left(\frac{1}{2}-\frac{1}{2+22,2 \cdot x}\right) \cdot 16.542 \cdot m$

Break-even point analysis method can be applied to analyze the heat savings and building's reconstruction costs:

$\left\{\begin{array}{l}S_{t}=\left(\frac{1}{2}-\frac{1}{2+22.2 x}\right) \cdot 16.542 \cdot m, \\ S_{r}=3.33 \cdot(420 \cdot x+15),\end{array}\right.$

where $m$ - the length of an investing period in years.

Research results are provided in the Figs. 5 and 6.

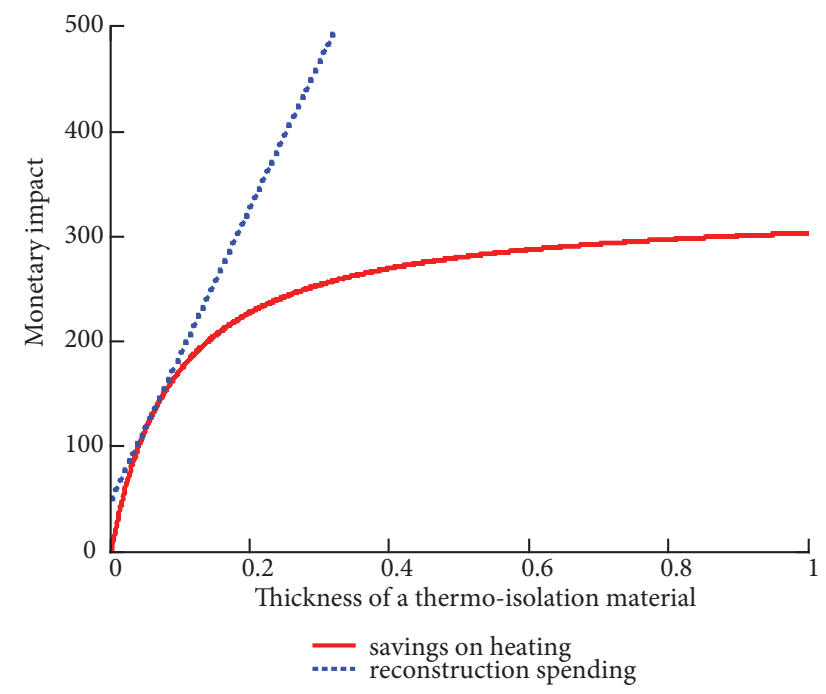

Fig. 5. Break-even analysis method applied to the estimation of revenues and costs associated with a thermoisolation process of a building wall with a pre-construction thermal resistance $R_{1}=2, m=40$ 


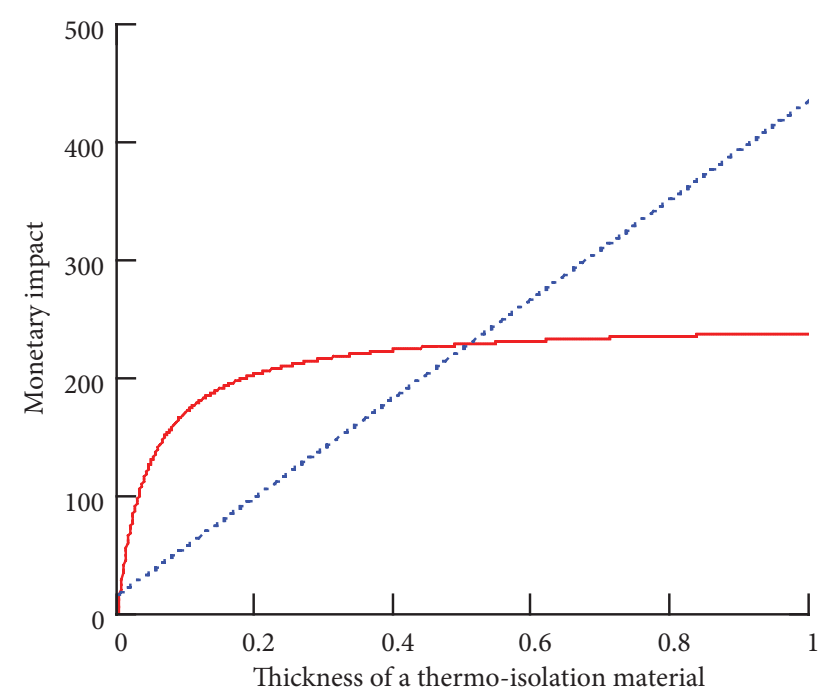

Fig. 6. Break-even analysis of a building wall with a preconstruction thermal resistance of $R_{1}=1$ when reconstruction works are self-executed, $m=15$

When the gas cost reaches $1.6 \mathrm{Lt} / \mathrm{m}^{3}$, and the price of a thermo-isolation material is at $420 \mathrm{Lt} / \mathrm{m}^{3}$ $\left(\lambda_{d s}=0.034 \mathrm{~W} /(\mathrm{mK})\right)$, a thermo-isolation of a building wall that has a pre-reconstruction thermal resistance of $R_{1}=2$ would result in a largest economic profit when the thermo-isolation material is $10 \mathrm{~cm}$ in thickness. Such building would reach a break-even point in 40 years.

Using the current costs of gas for heating and construction materials in Lithuania and assuming that the reconstruction works are self-executed, a thermoisolation of a building wall that has a pre-reconstruction thermal resistance of $R_{1}=1$ would result in a largest economic profit when the thickness of the thermo-isolation material is equal to $12 \mathrm{~cm}$. Such reconstruction works would reach a break-even point in 4 years. When the reconstruction works are self-executed, the profit per $\mathrm{m}^{2}$ of the wall obtained after 15 years would equal to $115 \mathrm{Lt}$.

\section{Conclusions}

1. Examples obtained using break-even point method in this article indicate that break-even analysis can be successfully applied in the evaluation of reconstruction work needs.

2. The need for a reconstruction in the industrial building should not be separated from a need for a renewal in a production process. Only the simultaneous treatment of these two issues will give the maximum economic effect to the owner.

3. The article shows that it is erroneous to assume that larger investments in building's thermo-isolation will continuously increase the economic.

4. When the gas cost reaches $1.6 \mathrm{Lt} / \mathrm{m}^{3}$, and the price of a thermo-isolation material is at $420 \mathrm{Lt} /$ $\mathrm{m}^{3}\left(\lambda_{d s}=0.034 \mathrm{~W} /(\mathrm{mK})\right)$, a thermo-isolation of a building wall that has a pre-reconstruction thermal resistance of $R_{1}=2$ would result in a largest economic profit when the thermo-isolation material is $10 \mathrm{~cm}$ in thickness. Such building would reach a break-even point in 40 years.

5. Using the current costs of gas for heating and construction materials in Lithuania and assuming that the reconstruction works are self-executed, a thermo-isolation of a building wall that has a pre-reconstruction thermal resistance of $R_{1}=1$ would result in a largest economic profit when the thickness of the thermo-isolation material is equal to $12 \mathrm{~cm}$. Such reconstruction works would reach a break-even point in 4 years. When the reconstruction works are selfexecuted, the profit per $\mathrm{m}^{2}$ of the wall obtained after 15 years would equal to $115 \mathrm{Lt}$.

\section{References}

Artmann, N.; Manz, H.; Heiselberg, P. 2008. Parameter study on performance of building cooling by night-time ventilation, Renewable Energy 33(12): 2589-2598.

doi:10.1016/j.renene.2008.02.025

Blanco, J.; Malato, S.; Gernjak, P. W.; Maldonado, M. I. 2009. Review of feasible solar energy applications to water processes, Renewable and Sustainable Energy Reviews 13(6-7): 14371445. doi:10.1016/j.rser.2008.08.016

Blaug, M. 2007. The Social Sciences: Economics, The New Encyclopedia Britannica, vol. 27: 347. Chicago.

Brauers, W. K.; Zavadskas, E. K. 2009. Robustness of the multiobjective MOORA method with a test for the facilities sector, Technological and Economic Development of Economy 15(2): 352-375. doi:10.3846/1392-8619.2009.15.352-375

Mingozzi, A.; Bottiglioni, S.; Matteo, M. 2009. Passive cooling of a bioclimatic building in the continental climate of the Padan Plain: analysing the role of thermal mass with dynamic simulations, International Journal of Sustainable Energy 28(1-3): 141-156. doi:10.1080/14786450802456309

STR 2.05.01:2005. The Technique of Building Heating (in Lithuanian).

Venckevicius, V. 2004. Maintenance and reconstruction of buildings, Construction Engineer's Manual. Vilnius: Technika. ISBN 9986-05-682-9. 


\section{EKONOMINIS REKONSTRUKCIJOS POREIKIO İVERTINIMAS}

\section{R. Tamošaitis}

Santrauka. Pastatų patvarumas ir išvaizda yra svarbūs dalykai visiems statiniams, tačiau rekonstrukcijos poreikị dažniausiai lemia ekonominè nauda. Gyvenamuosius statinius dažniausiai rekonstruojame siekdami sumažinti šildymo ir priežiūros išlaidas, o pramoninius pastatus - keisdami pasenusias technologijas naujomis ir tokiu būdu siekdami didesnio pelno. Šiame straipsnyje aprašoma nauja kritinio taško analizès metodu pagrịsta metodika, skirta rekonstrukcijos poreikio ekonominiam pagrịstumui nustatyti.

Reikšminiai žodžiai: statyba, rekonstrukcijos poreikis, kritinio taško analizès metodas.

Romualdas TAMOŠAITIS. Doctor, Associate Professor. Department of Construction Technology and Management. Vilnius Gediminas Technical University. First degree in civil engineering, Vilnius Gediminas Technical University (1982). Doctor (1991). Research visits to Glamorgan University (England, 1993) and Denmark Technical University (Denmark, 2007). Member of Lithuanian Technical Comity of Standards TK-39 "Security", Member of the EWG-MCDA Working Group within EURO since 2002. Author of about 70 different publikations. Research interests: construction technology and management. 